\title{
NON-ASBESTOS CAUSES OF MESOTHELIOMA AND TRANSLOCATION OF ASBESTOS FibRES
}

Singapore Med J 2015; 56(6): 361 doi: 10.11622/smedj.2015100

Dear Sir,

Akin et $\mathrm{l}^{(1)}$ provided an interesting report on mesothelioma of the tunica vaginalis. The authors mentioned several potential causative (risk) factors for the malignancy, notably asbestos, trauma, long-term hydrocele, herniorrhapy and viral infection (simian virus 40). Assuming asbestos was the causative factor, fibres from this mineral would need to migrate from the respiratory system after inhalation. Asbestos has been reported to translocate in the body from the lung or gastrointestinal system to numerous organs, including the tunica vaginalis. ${ }^{(2)}$ It has been suggested that translocation occurs through the blood and lymphatic systems and/or immune system cells (i.e. macrophages). ${ }^{(2)}$

In addition to those risk factors discussed by Akin et al, ${ }^{(1)}$ we would like to mention other factors that have been reported as potential causative agents for mesothelioma. These agents/substances include metals, rubber, scars, sugar cane, dietary factors, idiopathic, man-made mineral fibres, non-asbestos fibres/materials, infections, zeolite minerals, ionising radiation, inflammation, genetic factors, chemicals, synthetic agents, polymers, hydrocarbons, hormones and smoking. ${ }^{(3-5)}$ Although these agents have been reported to be associated with pleural and peritoneal mesothelioma, they may also be involved in causation of mesothelioma of the tunica vaginalis. ${ }^{(3-5)}$

Yours sincerely,

John $\mathrm{H} \underline{\text { Lange }}^{1}$, Luca $\underline{\text { Cegolon }}^{2}$

${ }^{1}$ Envirosafe Training and Consultants, Pittsburgh, PA, USA, ${ }^{2}$ London School of Hygiene and Tropical Medicine, Department of Infectious Disease Epidemiology, London, UK. Jhlange1@hotmail.com

\section{References}

1. Akin Y, Bassorgun I, Basara I, Yucel S. Malignant mesothelioma of tunica vaginalis: an extremely rare case presenting without risk factors. Singapore Med J 2015; 56:e53-5.

2. Miserocchi G, Sancini G, Mantegazza F, Chiappino G. Translocation pathways for inhaled asbestos fibers. Environ Health 2008 ; 7:4.

3. Lange JH. Re: "Mesothelioma trends in the United States: an update based on surveillance, epidemiology, and end results program data for 1973 through 2003". Am J Epidemiol 2004; 160:823.

4. Lange JH, Hoskins JA, Mastrangelo G. Non-asbestos causes of mesothelioma. In: Baldi A. Mesothelioma from bench side to clinic. New York: Nova Biomedical Books, 2008: 67-104.

5. Allen EM, Alexander BH, MacLehose RF, Ramachandran G, Mandel JH. Mortality experience among Minnesota taconite mining industry workers. Occup Environ Med 2014; 71:744-9.

Editor's note: The authors, Akin et al, have declined to respond to the above letter. 